\title{
The Use of Duolingo Apps to Improve English Vocabulary Learning
}

\author{
https://doi.org/10.3991/ijet.v15i07.13229 \\ Pangkuh Ajisoko \\ Borneo University of Tarakan, Kalimantan, Indonesia \\ pangkuh.ajisoko@gmail.com
}

\begin{abstract}
Education is a process of learning knowledge and skills. Learning English is skill-based learning that requires diverse approaches and techniques. Current education is much affected by technological advances. The use of technology is the latest solution to answer the challenges of learning English. As with advancement of English language learning means, duolingo completes to innovate way of learning language on mobile phone basis. The focus of this research is to explore the use of Duolingo apps in improving student's vocabulary in Borneo University of Tarakan. The research design of this research is pre-experimental research with pre-test and post-test. This research will involve 10 students as sample with 30 days practicing duolingo apps using "regular" intensity of practice ( $20 \mathrm{xp}$ per day). The Research instruments were tests and questionnaire to answer the research questions. How is the use of duolingo in improving students' vocabulary? Based on the quantitative data, the students' score is increased. The result is expected to provide information for teachers and students in having extensive language learning practice in handy form.
\end{abstract}

Keywords-Duolingo Apps, Vocabulary, English Learning

\section{$1 \quad$ Introduction}

Vocabulary cannot be detached from other facets of English language learning. Vocabulary is the basic component that must be mastered by learners so as to develop other language proficiencies like listening, speaking, reading, and writing. To have good English proficiency, the learners must have ample vocabulary. Richard [1] states that Vocabulary is a core component of language proficiency and provides much of the basic how well learners speak, listen, read, and write. Without an extensive vocabulary and strategies for acquiring new word, from making use language learning opportunities around them such as listening radio, listen to native speakers, using the language in different context, reading, or watching television.

Learning English language will be challenging if learners do not have adequate vocabulary. Teachers as the key of successful learning will have important role. Teachers 
must put emphasis in improving learners' vocabulary. Teachers are demanded to use the innovative way and media that increases students' enthusiasm in learning vocabulary. Most of teachers have already used the media in teaching and learning process, but forget to enhance vocabulary learning.

New media of learning English has been created. One of them uses apps that can be downloaded and installed through smartphone. The apps are called Duolingo. Hence, the writer needs to see how the influence of Duolingo in extensive learning of Borneo University of Tarakan. Duolingo is an open language learning application in Play store. As stated on their website, "Duolingo builds a world with free education and no language barriers. Users are able to learn languages for free while simultaneously translating web" [2].

Duolingo has a lot of language that learners choose to learn. English, Arabic, Spanish, French, Dutch, and other languages are available to select [3]. It also has educator's forum that the users can interchange subject and topics with each other either as teacher or student to learn [4]. It can measure learners' accomplishment and dedication with enjoyable ways. The apps provides information like point earned, of course overview tree, the streak, and the time spent [5]. The practices are so numerous and easy for novice learner to learn a new language. The apps are very simple to use, the procedures and steps are easy to understand. Duolingo targets to be friendly for all ages from children, teenagers, parents, and others [6]. Munday [7] stated that Duolingo is preferred than regular assignment and media because of its convenience. It means that Duolingo is easy to use and more interesting so it will be comfortable to be one of the media that used in teaching in classroom. Grego and Vesselinov [8], did a research that finds out the effectiveness of Duolingo in learning language. Their research showed that the students are satisfied in learning language with Duolingo and they enjoyed to learn with it.

This research aims at improving learners' vocabulary through Duolingo at second semester of students of Borneo University of Tarakan and to create excitement and interest in learning English extensively, especially vocabulary by using Duolingo.

\section{Method}

This study uses pre-experimental research with one group pre-test and post-test. Nineteen learners of second semester of 2018/2019 academic year of English Education Department in Borneo University of Tarakan were involved as participant in this study. They were asked to practice Duolingo 20 XP per day (points in Duolingo) every day for thirty days after they finished study in Campus. Learners' vocabulary mastery was measured by pre-test before they practice the apps. If the score of post-tests is higher than pre-test, it shows the improvement of learners' vocabulary and the treatment is effective as the media in teaching vocabulary.

Two instruments were used in this study. They are test and questionnaire. The test is to figure out the impact of Duolingo use and questionnaire is to perceive learners' perception after using Duolingo. The tests are pre-test and post-test. The pre-test was completed before using Duolingo. The pre-test consists of 25 questions of basic vocabulary. 
The aim of the test is to see learners' vocabulary mastery. Post-test was conducted after the treatment. The aim of this test is to see the scores of learners' vocabulary after implementing Duolingo. The post-test consists of 25 questions. Combined with the pretest result, the results will be investigated to see the impact of Duolingo in improving students' vocabulary.

The questionnaires are to discover the learners' perception after using Duolingo. The closed-ended questionnaire with the Likert-scale type was used in this study. The questionnaire has 12 questions. It consists of learners' interest, the disadvantages and the advantages of Duolingo. Learners completed the questionnaire at the last meeting.

\section{Results and Discussions}

\subsection{Result of pre-test and post-test}

In pre-test and post-test, the learners were asked to complete some questions related to learners' proficiency in English vocabulary. The questions type is the same but the questions are different to each other. The result of pre-test and post-test can be seen in the table 1 .

Table 1. Learners' Score

\begin{tabular}{|c|c|c|c|}
\hline No & Learners' Initial & Pre-test & Post-test \\
\hline 1 & TK & 72 & 72 \\
\hline 2 & AZ & 72 & 76 \\
\hline 3 & SY & 64 & 80 \\
\hline 4 & AT & 64 & 84 \\
\hline 5 & JI & 52 & 64 \\
\hline 6 & EA & 72 & 76 \\
\hline 7 & AA & 68 & 92 \\
\hline 8 & IN & 60 & 84 \\
\hline 9 & PJ & 68 & 72 \\
\hline 10 & MG & 64 & 80 \\
\hline 11 & YR & 48 & 68 \\
\hline 12 & RW & 46 & 72 \\
\hline 13 & NV & 44 & 80 \\
\hline 14 & NM & 60 & 84 \\
\hline 15 & MA & 44 & 84 \\
\hline 16 & LA & 48 & 92 \\
\hline 17 & AM & 40 & 80 \\
\hline 18 & FS & 48 & 80 \\
\hline 19 & AP & & 84 \\
\hline
\end{tabular}

Based on the table above, the highest score for Pre-Test is 72 and the lowest score is 44. There were just 3 students who get 72 , all of students were under the minimal criterion. To get the result of pre-test, the score was calculated to see the mean score. The 
mean score of the pre-test is 57.47 . It can be concluded that most of the learners' score was still low.

Based on the table above, the highest score for Post-Test is 92 and the lowest score is 64 . There were just 2 students who get 92 , all of students were above the minimal criterion. The mean score of the post-test is 79.15 .

Based on the table above, the highest score for Post-Test is 92 and the lowest score is 64 . There were just 2 students who get 92 , all of students were above the minimal criterion. The mean score of the post-test is 79.15 .

Based on the result of learners' score of pre-test and post-test, there was significant improvement of learners' average score. The mean score of pre-tests was 44.75 and the mean score of post-tests was 59.75. The significant score of their improvement is 0.678 .

\subsection{Result of questionnaire}

Questionnaire were used to obtain the data about learners' perception in using Duolingo as extensive learning of vocabulary. There are twelve questions in questionnaire. The data can be seen in following figures and description.

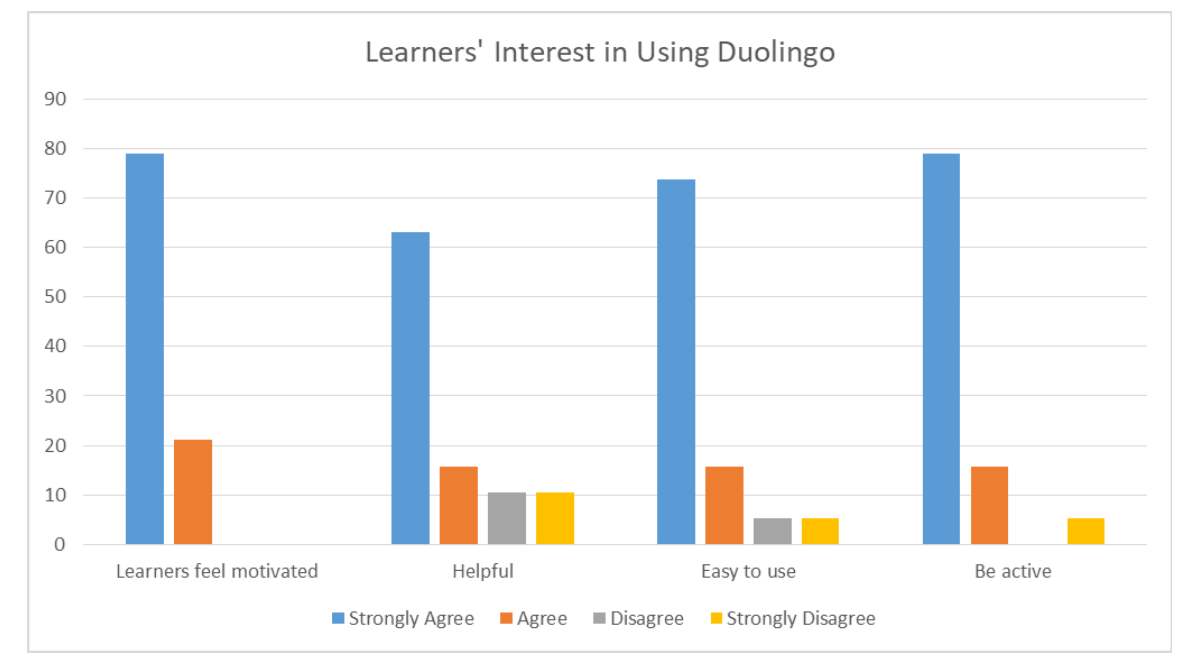

Fig. 1. Learners' Interest in Using Duolingo

Based on the data above, it was revealed that most of learners agree, $75 \%$ learners strongly agree and $17.5 \%$ agree if Duolingo makes learners interested to learn vocabulary. Most of learners feel that Duolingo motivates them, helpful, easy to use and makes them active in learning vocabulary. while $3.0 \%$ of them disagreed. It shows that Duolingo facilitates them in understanding and practicing their vocabulary. 


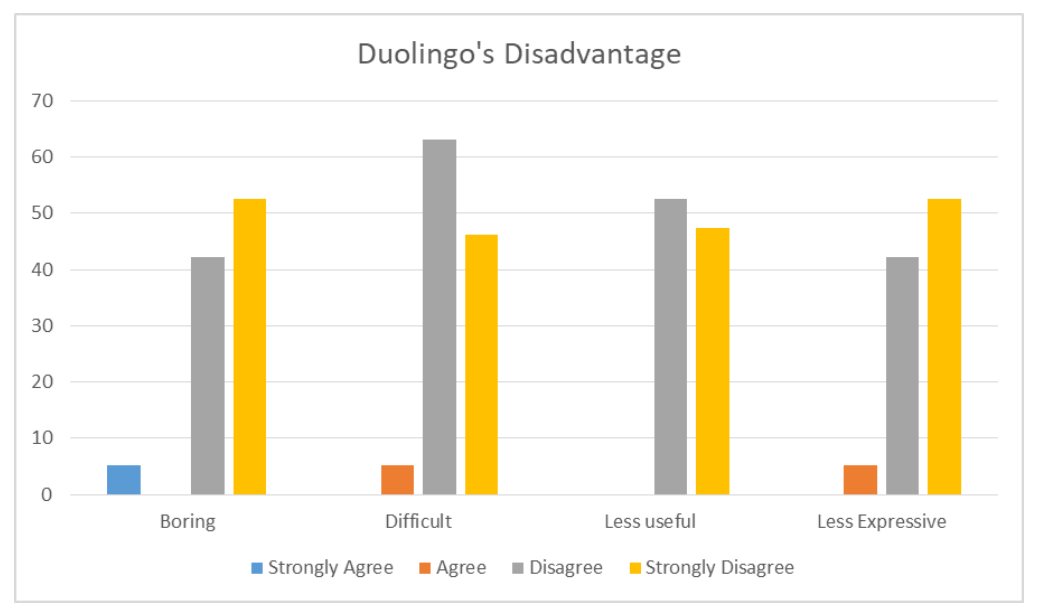

Fig. 2. Duolingo's Disadvantages based on Questionnaire

Based on the data above, it was revealed that most of students disagree, $49 \%$ learners strongly disagree and $48.5 \%$ disagree if Duolingo is boring, difficult, less useful and less expressive. while $3.0 \%$ of them agreed. It shows that Duolingo still needs to be improved.

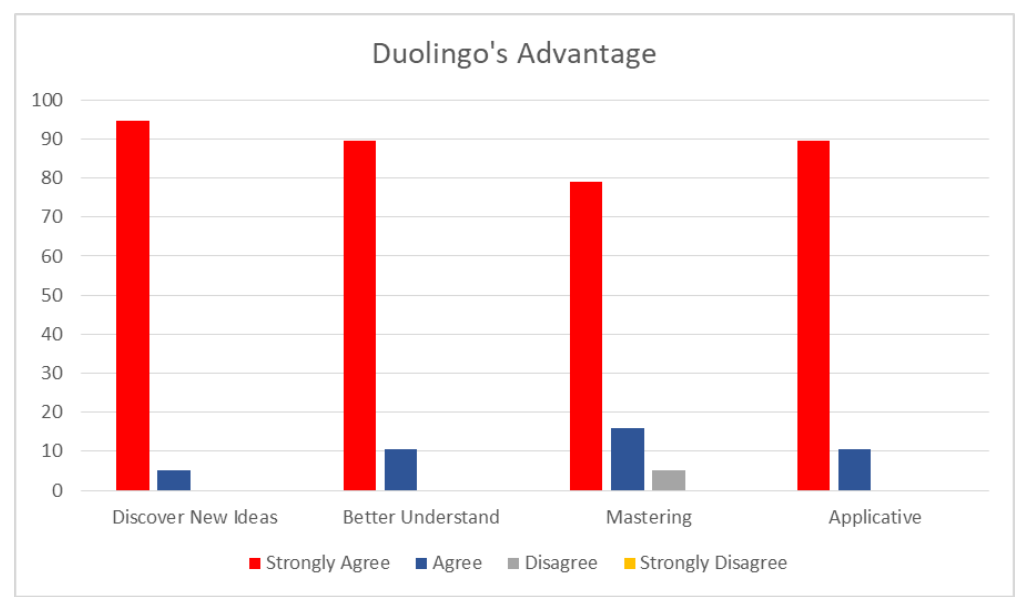

Fig. 3. Duolingo's Advantages based on Questionnaire

Based on the data above, it was revealed that most of learners agree, $89 \%$ learners strongly agree and $10 \%$ agree that Duolingo provides advantages in learning vocabulary. Most of learners feel that Duolingo helps them to discover new ideas, have better understanding, mastering vocabulary, and applicative to use. while $1.0 \%$ of them disagreed. It shows that Duolingo facilitates them in understanding and practicing their vocabulary. 
The study found that nearly all of learners obtained significant post-test score than pre-test. The data of post-test's score showed that there was development on learners' score. The mean score of post-tests is greater than pre-test $(57.45>79.15)$ which means that learners' vocabulary mastery has been improved. The significance of improvement is 0.687 . From that result, it showed that there was a significant improvement of students' scores before and after using Duolingo extensively.

The result from questionnaire revealed positive responses from learners. Learners were more motivated in learning; more skillful because the interest of learning increases; easy to understand the material; giving the opportunity to all learners to get a fair turn in practicing the material; eliminate boredom in learning; encourage new ideas; and facilitate students in remembering also practice the material in daily life.

\section{$4 \quad$ Research Implication}

Teachers in Industry Revolution 4.0 need to mix English language learning with technology. Most learners have smartphone to access information. Teachers should customize their teaching and learning with current technology and in easiest way. Duolingo can be one of the effective apps in improving English language learning especially vocabulary.

Duolingo is one of the effective media in teaching-learning vocabulary. It is considerably interesting for learners as they showed excellent responses toward this apps, they are easy to understand the material, having an opportunity to all learners to get a fair turn in practicing material, Duolingo can eliminate boredom in learning and also encourage them of new idea in learning.

\section{$5 \quad$ References}

[1] J. C. Richards and W. A. Renandya, "Project work: A means to promote language and content," in Methodology in language teaching: an anthology of current practice, 2002. https://doi.org/10.1017/cbo9780511667190.014

[2] V. Jašková, "Duolingo as a New Language-Learning Website and Its Contribution to eLearning Education.," Duolingo as a New Lang. Website Its Contrib. to e-Learning Educ., 2014.

[3] G. García Botero, F. Questier, and C. Zhu, "Self-directed language learning in a mobileassisted, out-of-class context: do students walk the talk?" Comput. Assist. Lang. Learn., 2019. https://doi.org/10.1080/09588221.2018.1485707

[4] R. Gafni, D. B. Achituv, and G. J. Rachmani, "Learning foreign languages using mobile applications,” J. Inf. Technol. Educ. Res., 2017.

[5] S. Krashen, “Does Duolingo 'Trump' University-Level Language Learning?” Int. J. Foreign Lang. Teach., 2014.

[6] J. Bustillo, C. Rivera, J. G. Guzmán, and L. Ramos Acosta, "Benefits of using a mobile application in learning a foreign language," Sist. y Telemática, 2017. https://doi.org/10.180 $\underline{46 / \text { syt.v15i40.2391 }}$ 
[7] P. Munday, "THE CASE FOR USING DUOLINGO AS PART OF THE LANGUAGE CLASSROOM EXPERIENCE," RIED. Rev. Iberoam. Educ. a Distancia, 2015. https://doi.org/10.5944/ried.19.1.14581

[8] R. Vesselinov and J. Grego, "Duolingo Effectiveness Study," City Univ. New York, USA, 2012.

\section{Author}

Pangkuh Ajisoko is working in English Education Department of Borneo University of Tarakan, Kalimantan, Indonesia. pangkuh.ajisoko@gmail.com.

Article submitted 2020-01-08. Resubmitted 2020-02-02. Final acceptance 2020-02-22. Final version published as submitted by the authors. 